\title{
Women with Severe Anemia in Labor: Adverse Clinical Outcomes
}

\author{
Dr. Ruchika Singh ${ }^{1}$, Dr. Mamta Gupta ${ }^{* 2}$, Dr. Vandana Saini ${ }^{3}$ \\ ${ }^{1}$ DNB Resident, Hindu Rao Hospital \& NDMC Medical College, Delhi \\ ${ }^{2}$ Consultant Gynaecologist, Kasturba Hospital, Delhi \\ ${ }^{2}$ Ex HOD Gynae, Hindu Rao Hospital \& NDMC Medical College, Delhi \\ ${ }^{3}$ Sr. Specialist, Hindu Rao Hospital \& NDMC Medical College, Delhi
}

*Author for correspondence - Mamta Gupta

\begin{abstract}
Background: Severely anemic women in labor is a challenging situation for the obstetrician with increased perinatal and maternal morbidity and mortality. Methods: Evaluation of feto-maternal outcomes in women reporting in labor with severe anemia (group A, n=50) and without anemia (group $\mathrm{B}, \mathrm{n}=50$ ) was done. Results: No maternal mortality and still birth was observed in any of the group. Preterm labor pains, hypertensive disease, occurred more in group A ( $\mathrm{p}$ value $0.003,0.037$ respectively). Blood transfusion was the commonest intervention required. Congestive heart failure developed (CHF) in 3 women in group A and none in group B. Mean birth weight was more in group B ( $\mathrm{p}$ value 0.002 ). Birth asphyxia and NICU admissions were more in group A neonates ( $\mathrm{p}$ value $0.012,0.017$ respectively). Puerperal morbidity was high in group A women ( $p$ value 0.001 ). Eight women had severe maternal morbidity and 1 woman had near miss event in severe anemia group. Conclusions: Severely anemic women reporting in labor have high maternal and perinatal morbidity.
\end{abstract}

Keywords: severe anemia in pregnancy, maternal outcome, perinatal outcome, pre-term births, near miss, severe maternal morbidity, blood transfusion

\section{Introduction}

Anaemia in pregnancy is one of the most common medical problem encountered by obstetricians, especially in developing countries. World Health Organization has reported, 35\% to $75 \%$ (56\% on average) of pregnant women in developing countries and $18 \%$ of women from industrialized countries are anemic ${ }^{[1]}$. Many of these women were already anemic at the time of conception. The prevalence of anemia is high in central Asia and has been reported as $62-85 \%$ in India ${ }^{[2,3,4,5]}$.

Anemia in pregnancy is defined as hemoglobin levels less than $11 \mathrm{gm} / \mathrm{dL}^{[4]}$. Severe anemia is defined as hemoglobin levels less than $7 \mathrm{gm} / \mathrm{dL}^{[4]}$. These women have decreased oxygen carrying capacity of blood. Severe anemia in women who are already in labour is a critical situation for the obstetrician with the risk of adverse feto-maternal outcomes. It is responsible for $20-40 \%$ of direct and indirect maternal deaths because of increased susceptibility to cardiac failure, sepsis and association with preeclampsia, antepartum haemorrhage, postpartum haemorrhage and thrombo-embolism ${ }^{[2,6,7]}$. Risk of preterm delivery, low birth weight, prematurity, intrauterine growth retardation, intrauterine death and birth asphyxia is increased causing increased perinatal morbidity and mortality ${ }^{[2,6,8,9]}$.

Most of these women are uneducated or not well educated, have low socioeconomic status and are unbooked, prevention has little role when these severely anemic women are seen during labor. However, timely diagnosis and treatment during the antenatal period can prevent many of the maternal mortalities and morbidities.

Studying the adverse clinical outcomes in these women, can give an input to develop a strategical plan for evaluation, anticipation and treatment of these labouring severely anaemic women. This will not only help in averting many life threatening conditions, but also improving the clinical outcomes in these women.

\section{Aims \& Objectives}

Evaluation of maternal and fetal outcome in pregnant women with severe anaemia and pregnant women without anemia reporting in labor.

\section{Material and Methods}

It is a prospective, observational study conducted from November 2017 to January 2018 in the Department of Obstetrics and Gynaecology, Hindu Rao Hospital and associated North Delhi Municipal Corporation Medical College, New Delhi, India.

Sample size has been calculated by the formula:

$\mathrm{n}=\left(\mathrm{Z}_{1-\alpha}\right)^{2} \mathrm{P}(1-\mathrm{P}) / \mathrm{D}^{2}$ 


\section{International Journal of Innovative Research in Medical Science (IJIRMS) Volume 04 Issue 01 Jan 2019, ISSN: 2455-8737, Imp. Factor - 4.102 \\ Available online at - www.ijirms.in}

Where $\mathrm{n}=$ sample size, $\mathrm{Z}_{1-\alpha}=1.96$ for $95 \%$ level of confidence, $\mathrm{P}=$ expected prevalence $=3.5 \%^{[10]}$

$\mathrm{D}=$ precision $=.05$. Putting all the values in the equation, $\mathrm{n}=51.9$ Sample size taken $=50$

\section{Inclusion Criteria-}

1. Pregnant women with $\mathrm{Hb}<7 \mathrm{gm} / \mathrm{dL}$ in labour (Group A).

2. Pregnant women with $\mathrm{Hb} \geq 11 \mathrm{gm} / \mathrm{dL}$ in labour (Group B).

\section{Exclusion Criteria-}

1. Pregnant women with haemoglobin between $7-10.9 \mathrm{~g} / \mathrm{dl}$

2. Not willing for participation

3. Women with severe anaemia at term or at the time of delivery due to acute bleeding (antepartum haemorrhage) for group A

4. History of hemoglobinopathy

5. Multiple pregnancy.

6. Pregnant women with pre-existing medical comorbidities.

All women at the time of admission in the labor ward had CBC or complete blood count done (haemoglobin included in CBC) by auto analyzer. A total of 50 pregnant women with severe anaemia $(\mathrm{Hb}<7 \mathrm{~g} / \mathrm{dL})$ were enrolled after informed written consent and fulfilling the inclusion and exclusion criteria for the study group (Group A). Age matched 50 healthy pregnant women without anaemia $(\mathrm{Hb} \geq 11 \mathrm{~g} / \mathrm{dL})$, fulfilling the inclusion and exclusion criteria were enrolled for the control group (Group B).

Baseline characteristics, symptoms of anemia, details of present pregnancy, history of iron and folic acid intake, blood transfusion if any, obstetric history was recorded. General, systemic examination and per abdomen examination was done. Per vaginum examination was done at the time of admission and later to assess fetal wellbeing and progress of labor.

Peripheral smear was done in all women at the initial evaluation at the time of admission to labor ward. Women were observed in labour with strict watch on fetal heart rate pattern and progress of labor. Regular intrapartum and postpartum assessment was done. They were managed in labour as per our standard protocol. Maternal outcomes (preterm labour, preeclampsia, antepartum haemorrhage, infections if any, cardiac failure, requirement of blood, labour details, complications during labour, post-partum complications, duration of hospital stay) were recorded in a predesigned proforma. Neonatal outcome including APGAR score and fetal weight estimation, congenital anomaly if any, need for NICU, neonatal mortality were also recorded.

Women were observed in post-natal ward for any interventions or development of any complication i.e. CHF, pulmonary edema, infections (urinary tract infections, respiratory infections, malaria, viral fever, tuberculosis or puerperal sepsis etc.), DVT (deep venous thrombosis), establishment of lactation, requirement of transfusions or parenteral iron, maternal mortality or need of ICU admission etc. Duration of hospital stay was also recorded. All the above details were recorded.

Statistical Methods: Statistical analysis was done with the statistical package for the social science system version SPSS 20. Continuous variables were presented as mean \pm SD. The data was presented in terms of frequencies and percentages for categorical variables. Categorical data analysis was carried out using Chisquared test or Fisher's exact test as appropriate. The comparison of normally distributed continuous variables was performed using Student's t test. For all statistical tests, $\mathrm{p}$ value $<0.05$ was taken as significant difference.

\section{Results}

Table 1: Baseline demographic and haematological parameters

\begin{tabular}{|l|c|c|c|}
\hline Parameter & $\begin{array}{c}\text { Group A } \\
\text { n \% }\end{array}$ & $\begin{array}{c}\text { Group B } \\
\text { n \% }\end{array}$ & P value* \\
\hline Age mean (years) & $24.20 \pm 3.66$ & $25.58 \pm 3.43$ & 0.06 \\
\hline Religion -Hindu (n=88) & 44 & 44 & 1 \\
Muslim (n=12) & 6 & 6 & $0.8 \pm 0.78$ \\
\hline Parity mean & $1.2 \pm 1.08$ & $21.78 \pm 1.91$ & 0.006 \\
\hline Mean BMI \pm SD & $19.63 \pm 3.21$ & $2290.00 \pm 239.26$ & 0.001 \\
\hline Mean calorie intake & $1828.00 \pm 241.63$ & $5(10.0 \%)$ & 0.001 \\
\hline Antenatal booking & $13(26.0 \%)$ & $6(12.0 \%)$ & 0.001 \\
Unbooked (n=18) & $18(36.0 \%)$ & $39(78.0 \%)$ & 0.0001 \\
Registered (n=24) & $19(38.0 \%)$ & $38.55 \pm 1.48$ & 0.001 \\
Booked (n=58) & $37.20 \pm 2.25$ & $3(6 \%)$ & \\
\hline Gestational age (mean wks) & $34(34 \%)$ & $12.35 \pm 0.83$ & 0.001 \\
\hline **Symptoms of anemia & $5.8 \pm 0.87$ & & \\
\hline Hb mean (g/dl) & & $0(0.0 \%)$ & $0(0.0 \%)$ \\
\hline Peripheral smear & $43(86.0 \%)$ & $0(0.0 \%)$ & $5(100.0 \%)$ \\
Microcytic Hypochromic & $3(6.0 \%)$ & $4(8.0 \%)$ & \\
Macrocytic & $0(0.0 \%)$ & & \\
Dimorphic & & & \\
Normocytic-normochromic & & & \\
\hline
\end{tabular}

$* P$ value $<0.05$ is significant .

**Symptoms included weakness, tiredness, palpitation, dyspnoea etc. 


\section{International Journal of Innovative Research in Medical Science (IJIRMS) Volume 04 Issue 01 Jan 2019, ISSN: 2455-8737, Imp. Factor - 4.102 \\ Available online at $-\underline{w w w . i j i r m s . i n}$}

Table 2: Iron supplements \& blood transfusion in antenatal period

\begin{tabular}{|c|c|c|c|}
\hline Parameter & $\begin{array}{c}\text { GROUP A } \\
\text { n } \%\end{array}$ & $\begin{array}{l}\text { GROUP B } \\
\text { n } \%\end{array}$ & p value* \\
\hline $\begin{array}{l}\text { Intake of iron-folic acid YES } \\
\text { NO }\end{array}$ & $\begin{array}{l}36(72 \%) \\
14(28 \%)\end{array}$ & $\begin{array}{c}45(90 \%) \\
5(10 \%)\end{array}$ & 0.02 \\
\hline $\begin{array}{l}\text { Compliant for iron folic acid intake } \\
\text { Non compliant for iron-folic acid }\end{array}$ & $\begin{array}{l}18(36.0 \%) \\
18(36.0 \%)\end{array}$ & $\begin{array}{c}40(80.0 \%) \\
5(10.1 \%)\end{array}$ & 0.001 \\
\hline Parenteral iron received $(n=7)$ & $5(10.0 \%)$ & $2(4.0 \%)$ & 0.24 \\
\hline Transfusion received $(\mathrm{n}=2)$ & $2(4.0 \%)$ & $0(0.0 \%)$ & 0.15 \\
\hline
\end{tabular}

$* P$ value $<0.05$ is significant

Table 3: *Medical diseases/complications associated during antenatal period

\begin{tabular}{|c|c|c|c|}
\hline Medical disease/complication & $\begin{array}{c}\text { Group A } \\
\text { n }(\%)\end{array}$ & $\begin{array}{c}\text { Group B } \\
\text { n }(\%)\end{array}$ & P value $^{\wedge}$ \\
\hline $\begin{array}{l}* * \text { Women with complications }(\mathrm{n}=28) \text { Women with no } \\
\text { complications }(\mathrm{n}=72)\end{array}$ & $\begin{array}{l}21(42.0 \%) \\
29(58.0 \%)\end{array}$ & $\begin{array}{l}7(14.0 \%) \\
43(86.0 \%)\end{array}$ & 0.002 \\
\hline Respiratory infections $(n=2)$ & $1(2.0 \%)$ & $1(2.0 \%)$ & 1 \\
\hline Lower urinary tract infection(LUTI) $(\mathrm{n}=5)$ & $4(8.0 \%)$ & $1(2.0 \%)$ & 0.169 \\
\hline Fever $(n=8)$ & $7(14.0 \%)$ & $1(2.0 \%)$ & 0.027 \\
\hline Diarrhoea $(n=8)$ & $6(12.0 \%)$ & $2(4.0 \%)$ & 0.140 \\
\hline Jaundice $(n=1)$ & $1(2.0 \%)$ & $0(0.0 \%)$ & 0.315 \\
\hline Hypothyroidism $(\mathrm{n}=11)$ & $6(12 \%)$ & $5(10 \%)$ & 0.749 \\
\hline Thrombocytopenia $(\mathrm{n}=7)$ & $5(10.0 \%)$ & $2(4.0 \%)$ & 0.240 \\
\hline$* *$ Total medical complications $(n=42)$ & 30 & 12 & 0.001 \\
\hline
\end{tabular}

*Pre-existing/pre-pregnancy medical diseases were excluded from the study

**Many women had more than one complications/disease hence, the discrepancy.

${ }^{\wedge} p$ value $<0.05$ is significant

Table 4: Obstetric outcomes during antenatal period

\begin{tabular}{|c|c|c|c|}
\hline Obstetric Complications / conditions associated & $\begin{array}{c}\text { Group A } \\
\text { n }(\%)\end{array}$ & $\begin{array}{c}\text { Group A } \\
\text { n }(\%)\end{array}$ & $\begin{array}{c}* * * \mathbf{P} \\
\text { value }\end{array}$ \\
\hline *Women with obstetrical complications $(n=44)$ & $29(58.0 \%)$ & $15(30.0 \%)$ & 0.005 \\
\hline Women with no obstetrical complications $(\mathrm{n}=56)$ & $21(42.0 \%)$ & $35(70.0 \%)$ & \\
\hline Gestational HT, pre-eclampsia(GH,PE) $(\mathrm{n}=13)$ & $10(20.0 \%)$ & $3(6.0 \%)$ & 0.037 \\
\hline Fetal growth restriction (FGR) $(n=7)$ & $5(10.0 \%)$ & $2(4.0 \%)$ & 0.24 \\
\hline Oligohydramnios $(\mathrm{n}=6)$ & $3(6.0 \%)$ & $3(6.0 \%)$ & 1 \\
\hline Intra-hepatic cholestasis of pregnancy $(\mathrm{n}=3)$ & $2(4.0 \%)$ & $1(2.0 \%)$ & 0.56 \\
\hline Gestational diabetes mellitus (GDM) $(n=3)$ & $4(8.0 \%)$ & $3(6.0 \%)$ & 0.69 \\
\hline Pre-mature rupture of membranes (PROM) $(\mathrm{n}=5)$ & $3(6.0 \%)$ & $2(4.0 \%)$ & 0.65 \\
\hline Preterm labour pains $(\mathrm{PTL})(\mathrm{n}=20)$ & $16(32.0 \%)$ & $4(8.0 \%)$ & 0.003 \\
\hline *Total number of complications $(\mathrm{n}=61)$ & 43 & 18 & \\
\hline
\end{tabular}

*Many women had more than one complication hence, the discrepancy.

$* * p$ value $<0.05$ is significant

Table 5: Maternal outcomes in $1^{\text {st }} \& 2^{\text {nd }}$ stage of labor

\begin{tabular}{|l|c|c|c|}
\hline Intrapartum events/complications in $\mathbf{1}^{\text {st }}, \mathbf{2}^{\text {nd }}$ stage of labor & $\begin{array}{c}\text { Group A } \\
\mathbf{n}(\boldsymbol{\%})\end{array}$ & $\begin{array}{c}\text { Group B } \\
\mathbf{n}(\boldsymbol{\%})\end{array}$ & *p value \\
\hline Women with no complications (n=44) & $\begin{array}{c}1(2 \%) \\
4 *(98 \%)\end{array}$ & $\begin{array}{c}43(86 \%) \\
7(14 \%)\end{array}$ & 0.027 \\
\hline CHF & $1(4.8 \%)$ & $0(0 \%)$ & 0.31 \\
\hline Acute dyspnoea & $4(8 \%)$ & $0(0 \%)$ & 0.04 \\
\hline Transfusion received & $45(90 \%)$ & $0(0 \%)$ & 0.001 \\
\hline Maternal exhaustion & $2(4 \%)$ & $0(0 \%)$ & 0.15 \\
\hline Fetal distress & $12(24 \%)$ & $4(8 \%)$ & 0.03 \\
\hline Meconium stained liquor & $6(12 \%)$ & $4(8 \%)$ & 0.50 \\
\hline Prolonged second stage & $0(0.0 \%)$ & $1(2 \%)$ & 0.31 \\
\hline Precipitate labour & $2(4 \%)$ & $0(0 \%)$ & 0.15 \\
\hline$*$ Total complications/events in $1^{\text {st }} \& 2^{\text {nd }}$ stage & 72 & 9 & 0.001 \\
\hline
\end{tabular}

*p value $<0.05$ is significant.

** Many women had more than one complication/event hence, the discrepancy 


\section{International Journal of Innovative Research in Medical Science (IJIRMS) Volume 04 Issue 01 Jan 2019, ISSN: 2455-8737, Imp. Factor - 4.102 \\ Available online at $-\underline{w w w . i j i r m s . i n}$}

Table 6: Maternal outcomes in $3^{\text {rd }}$ stage of labor

\begin{tabular}{|l|c|c|c|}
\hline $\mathbf{3}^{\text {rd }}$ stage complications & $\begin{array}{c}\text { Group A } \\
\mathbf{n}(\boldsymbol{\%})\end{array}$ & $\begin{array}{c}\text { Group B } \\
\mathbf{n}(\boldsymbol{\%})\end{array}$ & *p value \\
\hline Women with complication $(\mathrm{n}=12)$ & $10(20 \%)$ & $2(4 \%)$ & 0.014 \\
Women with no complication (n=88) & $40(80 \%)$ & $48(96 \%)$ & 0.04 \\
\hline PPH (n=10) & $8(16 \%)$ & $2(4 \%)$ & 0.153 \\
\hline CHF $(\mathrm{n}=2)$ & $2(4 \%)$ & $0(0 \%)$ & \\
\hline
\end{tabular}

*p value <0.05 is significant

Table 7: Perinatal outcomes

\begin{tabular}{|c|c|c|c|}
\hline Neonatal Outcome & $\begin{array}{c}\text { Group A } \\
\text { n }(\%)\end{array}$ & $\begin{array}{c}\text { Group B } \\
\text { n }(\%)\end{array}$ & p value* \\
\hline Women with neonatal complications $(n=40)$ & $29(58 \%)$ & $11(22 \%)$ & 0.001 \\
\hline Women without neonatal complications $(\mathrm{n}=60)$ & $21(42 \%)$ & $39(78 \%)$ & \\
\hline Still births $(\mathrm{n}=0)$ & $0(0.0 \%)$ & $0(0.0 \%)$ & 1 \\
\hline Birth weight(kg)- Normal $\geq 2.5(\mathrm{n}=74)$ & $32(64 \%)$ & $42(84 \%)$ & 0.02 \\
\hline Low birth weight $(\mathrm{kg}) 1.50-2.49(\mathrm{n}=25)$ & $17(34 \%)$ & $8(16 \%)$ & 0.03 \\
\hline Very low birth weight $(\mathrm{kg}) 1.0-1.49(\mathrm{n}=1)$ & $1(2 \%)$ & $0(0 \%)$ & 0.26 \\
\hline Mean birth weight $(\mathrm{kg})$ & $2.56 \pm 0.36$ & $2.79 \pm 0.37$ & 0.002 \\
\hline Small for gestation age $(\mathrm{SGA})(\mathrm{n}=7)$ & $5(10.0 \%)$ & $2(4.0 \%)$ & 0.46 \\
\hline APGAR score $<7$ - At 1 minute $(n=38)$ & $28(57 \%)$ & $10(20 \%)$ & 0.001 \\
\hline At 5 minutes $(n=26)$ & $21(42 \%)$ & $5(10 \%)$ & 0.001 \\
\hline NICU admissions $(\mathrm{n}=17)$ & $13(36 \%)$ & $4(8 \%)$ & 0.02 \\
\hline Early neonatal death $(\mathrm{n}=2)$ & $2(4 \%)$ & $0(0 \%)$ & 0.15 \\
\hline Birth asphyxia $(n=15)$ & $12(24 \%)$ & $3(6 \%)$ & 0.01 \\
\hline Meconium aspiration $(n=4)$ & $3(6 \%)$ & $1(2 \%)$ & 0.30 \\
\hline Neonatal sepsis $(n=1)$ & $1(2 \%)$ & $0(0 \%)$ & 0.31 \\
\hline Congenital anomaly $(\mathrm{n}=0)$ & $0(0 \%)$ & $0(0 \%)$ & 1 \\
\hline Jaundice $(n=6)$ & $4(8 \%)$ & $2(4 \%)$ & 0.4 \\
\hline
\end{tabular}

${ }^{*} p$ value $<0.05$ is significant

Table 8: Maternal outcomes during puerperium

\begin{tabular}{|l|c|c|c|}
\hline Puerperal complications & $\begin{array}{c}\text { Group A } \\
\text { n \% }\end{array}$ & $\begin{array}{c}\text { Group B } \\
\text { n \% }\end{array}$ & p value** \\
\hline *Women with complications & $18(36 \%)$ & $3(6 \%)$ & 0.001 \\
Women without complications & $32(64 \%)$ & $47(94 \%)$ & 0.31 \\
\hline Secondary PPH (n=1) & $1(2 \%)$ & $0(0 \%)$ & - \\
\hline CHF (n=0) & $0(0 \%)$ & $0(0 \%)$ & 0.007 \\
\hline Puerperal febrile illness (n=13) & $11(22 \%)$ & $2(4 \%)$ & 0.03 \\
\hline Infections (Respiratory tract \& UTI) (n=8) & $7(14 \%)$ & $1(2 \%)$ & 0.31 \\
\hline Wound sepsis (n=1) & $1(2 \%)$ & $0(2 \%)$ & 0.31 \\
\hline Pulmonary embolism (n=1) & $1(2 \%)$ & $0(0 \%)$ & 0.31 \\
\hline Shock (n=1) & $1(2 \%)$ & $0(0 \%)$ & 0.31 \\
\hline ICU admission (n=1) & $1(2 \%)$ & $0(0 \%)$ & 0.04 \\
\hline Delayed Lactation $(\mathrm{n}=4)$ & $4(8 \%)$ & $0(0 \%)$ & 0.001 \\
\hline Transfusion of packed blood cells (n=30) & $27(54 \%)$ & $3(6 \%)$ & 0.001 \\
\hline Parenteral iron $(\mathrm{n}=52)$ & $50(100 \%)$ & $2(4 \%)$ & 0.001 \\
\hline Mean duration of hospital stay (days) & 6 & 2 & \\
\hline
\end{tabular}

*Many women had than 1 complication/intervention. ${ }^{* *} p$ value $<0.05$ is significant.

Table 9: Association of mean hemoglobin with feto-maternal complications

\begin{tabular}{|c|c|c|}
\hline Variable & $\begin{array}{c}\text { Hemoglobin } \\
\text { Mean g/dL } \pm \text { SD }\end{array}$ & p value* \\
\hline Women with obstetric complication in antenatal period & $8.04 \pm 3.05$ & 0.007 \\
\hline Women without obstetrics complications in antenatal & $9.87 \pm 3.43$ & \\
\hline Women with medical complications in ANC & $7.17 \pm 2.99$ & 0.001 \\
\hline Women without medical complication in ANC & $9.83 \pm 3.24$ & \\
\hline Women with complications during $1^{\text {st }} \& 2^{\text {nd }}$ stage labour & $7.17 \pm 2.94$ & 0.001 \\
\hline Women without complications in $1^{\text {st }} \& 2^{\text {nd }}$ stage labour & $9.95 \pm 3.22$ & \\
\hline
\end{tabular}




\section{International Journal of Innovative Research in Medical Science (IJIRMS) Volume 04 Issue 01 Jan 2019, ISSN: 2455-8737, Imp. Factor - 4.102 \\ Available online at - www.ijirms.in}

\begin{tabular}{|l|c|c|}
\hline Women with complications in $3^{\text {rd }}$ stage & $6.85 \pm 2.94$ & 0.01 \\
Women without complications in $3^{\text {rd }}$ stage & $9.39 \pm 3.34$ & 0.001 \\
\hline Women with complications in puerperium & $6.84 \pm 2.23$ & $9.76 \pm 3.38$ \\
Women without complications in puerperium & $7.53 \pm 2.88$ & 0.001 \\
\hline Women with neonatal complications & $10.13 \pm 3.30$ & \\
Women without neonatal complications & & \\
\hline
\end{tabular}

*p value $<0.05$ is significant

\section{Discussion}

Evaluation of fetomaternal outcome in 50 pregnant women with severe anaemia with $\mathrm{Hb}<7 \mathrm{gm} / \mathrm{dL}$ and 50 non-anaemic pregnant women with $\mathrm{Hb} \geq 11 \mathrm{gm} / \mathrm{dL}$ admitted in labour was done. All the women were followed up postpartum till discharge. Most of the women in group A had microcytic hypochromic type of anemia (Table 1) similar to other studies ${ }^{[10,11]}$. Milman has suggested iron deficiency as the commonest cause of anemia ${ }^{[12]}$. Significant number of women had symptoms related to anaemia i.e. weakness, tiredness, palpitation, shortness of breath/dyspnoea etc. in group A compared to only $6 \%$ in group B (Table 1 ). Maka et al has reported $81 \%$ of anemic women having symptoms ${ }^{[6]}$.

Unbooked women were significantly more in group A, similar to other studies ${ }^{[13,7]}$ in which obstetric risks are found to be high ${ }^{[11]}$. Illiteracy, poverty, lack of awareness of prenatal care and accessibility of health facilities might be the factors that women do not come for availing antenatal services. Awareness for consuming iron-folic acid tablets was only $38 \%$ in rural pregnant women of Tamilnadu by Gopalakrishnan et $\mathrm{al}^{[14]}$. Intake of iron folic acid tablets during pregnancy was quite low in our study (72\% in group A compared to $90 \%$ in group B) (Table 2). Low intake of iron folic acid is directly related to anemic status of pregnant woman ${ }^{[15]}$. As many women were unbooked or registered in group A in our study, anemia remained undetected and untreated during pregnancy hence, parenteral iron and blood transfusions administration was comparable in the 2 groups (Table 2).

Infections were an important and common cause of morbidity in severely anaemic women. Fever, UTI, diarrhea, jaundice during antenatal period (Table 3) and puerperal febrile morbidity, respiratory infections, UTI wound sepsis during puerperium were found to be more in group A (Table 7). A higher rate of wound infection of $16 \%, 7.8 \%$ has been reported in anaemic women ${ }^{[16,17]}$. Iron deficiency is associated with impairment of innate and cell mediated immunity, contributing to increased risk of infections. Iron is an integral component of enzyme myeloperoxidase (MPO), which produces reactive oxygen intermediates responsible for intracellular killing of pathogen. This decreased MPO activity gets reversed once iron deficiency is corrected ${ }^{[18]}$. Hence, infections need to be evaluated and treated at the earliest in these women.

Significant higher obstetric morbidity/complications during antenatal period was observed in our study (58\% versus $30 \%$ in group A and B respectively) emphasising the need for specialised and focussed antenatal care for these anaemic women (Table 4).

A significant higher rate of complications was observed in all the three stages of labor in group A women. Blood transfusion was required by $90 \%$ women in group A compared to none in group B (Table 5). Studies have reported $100 \%$ women in severe anemia group received blood transfusion ${ }^{[19,13,10]}$.
Three women $(6 \%)$ developed CHF in our study, one in $1^{\text {st }}$ stage and two women in $3^{\text {rd }}$ stage of labor in group A whereas none had so in group B (Table 5,6). CHF was reported in $1.74 \%, 1.06 \%$, $6.15 \%$ in anaemic women ${ }^{[19,20,13]}$. Four women $(8 \%)$ in group A developed acute dyspnoea and were treated immediately and CHF was averted. This observation of impending CHF was quite significant. A strict vigil, timely detection and treatment of impending CHF can prevent many maternal mortalities in these women.

PPH was significantly more common in severe anaemia group (16\% in group A versus $4 \%$ in group B) (Table 6). Severe anaemia may impair myometrial contractility resulting from impaired transport of oxygen to uterus causing tissue enzymes and cellular dysfunction, leading to increased risk of atonic $\mathrm{PPH}^{[10,17]}$. A strong negative correlation between low $\mathrm{Hb}$ levels and blood loss was observed by Frass KA $(r=-.619 \text {, p value }<0.00)^{[21]}$. Wandabwa J et al has reported chronic anaemia as a predictor for PPH (OR 17.3, 95\% CI: $9.5-31.7)^{[22]}$.

Commonest obstetric complication observed in our study was preterm labour pains in group A (32\%) compared to group B (8\%) (Table 4). PTL was reported in $42.31 \%, 47.87 \%, 34 \%$, women respectively in severely anaemic women ${ }^{[13,20,16]}$. Low haemoglobin levels may cause a state of low-grade chronic hypoxia that induces maternal and fetal stress. An activated immune system in the presence of infections and inflammation and corticotrophinreleasing hormone or cortisol that are released following stress response, can activate the maternal or fetal hypothalamicpituitary-adrenal axis. Iron deficiency may also increase oxidative stress resulting in damage to erythrocytes and the feto-placental unit. This, in turn, can initiate labour and eventually result in preterm parturition $^{[23]}$.

Incidence of hypertensive disease of pregnancy was significantly higher (20\%) in group A compared to $(6 \%)$ in our study (Table 4). Ali AA has reported an incidence of pre-eclampsia and eclampsia as $8.2 \%$ and $3.3 \%$ respectively in severe anemia ${ }^{[24]}$. Other studies have reported PE in $20 \%, 22.3 \%$ anemic women respectively ${ }^{[10,13]}$. The susceptibility of women with severe anaemia to preeclampsia could be explained by a deficiency of micronutrients and antioxidants. A reduction in serum levels of calcium, magnesium and zinc during pregnancy might be possible contributors to the development of preeclampsia ${ }^{[25]}$.

Besides pre-eclampsia, the effect of maternal anaemia on intrauterine growth is attributed to chronic deprivation of oxygen to the developing fetus. Severe maternal anaemia, if present from early gestation, may be associated with reduced placental weight and surface area of peripheral villi which, is a determinant of nutrient transport from the mother to the fetus ${ }^{[26]}$. FGR was seen in $10 \%$ cases in our study, however, Yadav $\mathrm{P}$ has reported its incidence as $20 \%{ }^{[10]}$. A systematic review by Kozuki $\mathrm{N}$ concluded that 


\section{International Journal of Innovative Research in Medical Science (IJIRMS) Volume 04 Issue 01 Jan 2019, ISSN: 2455-8737, Imp. Factor - 4.102 \\ Available online at $-\underline{w w w . i j i r m s . i n}$}

haemoglobin of $<90$ - or $<80$-g/L category was associated with a $53 \%$ increase in risk of SGA babies ${ }^{[26]}$.

Mean birth weight was significantly lower in group A compared to group B $(2.56 \pm .364$ versus $2.79 \pm .370 \mathrm{~kg})$ due to PTL, FGR and SGA babies (Table 7), which is similar to observations by Riffat et al, Ghimire et al $[17,16]$. Risk of low birth weight has been reported to be 3.6 times higher amongst anemic mothers ${ }^{[27]}$.

APGAR score $(<7)$ was found to be significantly lower in group A compared to group B (Table 7). Sangeeta VB et al concluded that newborns of anemic mothers had 1.6 times increased risk of having an Apgar score of $<5$ at $1 \mathrm{~min}^{[8]}$. NICU admissions were significantly more in group A compared to group B (36\% versus $8 \%$ ) in our study. Batar A also has observed high NICU admissions of $43.08 \%$ in babies of anemic women ${ }^{[13]}$. Thus, a higher rate of neonatal complication has been observed in neonates of severly anemic women probably due to chronic deprivation of oxygen from maternal blood.

Though no still birth occurred in any of the group in our study (Table 7), a 4.3 times risk of stillborns have been reported ${ }^{[24]}$. Naushaba et al in her study has reported a significant higher perinatal mortality in $2.3 \%$ and intrauterine death in $8.9 \%$ in anemic women ${ }^{[28]}$. Only $2(4 \%)$ neonatal deaths occurred in group A due to milk aspiration in one and prematurity with birth asphyxia in the second baby. Only one baby developed sepsis in our study.

Significant higher maternal morbidity in puerperium caused increased hospital stay. Parenteral iron was administered to all $(100 \%)$ women to build up iron stores and prevent further maternal morbidity (Table 8).

Severe maternal morbidity (SMM) was seen in $16 \%(n=8)$ women in group A. Three women developed CHF and 1 woman during puerperium developed hypovolemic shock due to secondary PPH (Table 6,7,8). Four women in group A developed acute dyspnea during antenatal period, were immediately treated and CHF was averted (Table 3 ).

In our study, one woman in group A had near miss. She had postpartum tachypnoea, was clinically diagnosed as pulmonary embolism (Table 8) and was shifted to ICU; her D dimer was found to be raised significantly (we have no facility for ventilation perfusion scan). She responded to anti - coagulants very well and recovered. Women with pulmonary embolism had significantly lower mean haemoglobin and lower total serum proteins resulting in low blood viscosity. Decreased secretion of anti-thrombotic mediators, initiated by low blood viscosity in anemic states, resulted in increased clotting ${ }^{[29]}$. However, no relationship between anemia and the presence of pulmonary embolism was found ${ }^{[30]}$.

Severe anaemia was observed in $20.9 \%$ and $22 \%$ of near miss cases $^{[31,32]}$. Though, WHO has not categorized severe anaemia as a separate condition for baseline assessment of quality of severe maternal complications ${ }^{[33]}$, however, it has been suggested that severe anaemia should be listed as an independent cause for severe maternal morbidity ${ }^{[32]}$.

No maternal mortality occurred in any of the group. Though, maternal deaths were reported in severely anemic women in $8 \%$, $0.99 \%$ and $0.47 \%$ in various studies ${ }^{[10,24,7]}$.
Significant low mean haemoglobin was associated with women who had complications compared to women who did not had any complications during antenatal period, labor, puerperium and in women with neonatal complications (Table 9).

\section{Conclusions}

Severely anemic women reporting in labor had significantly high maternal and perinatal morbidity. These women should be delivered in a tertiary care hospital for dealing with severe maternal morbidity including near miss events and also high perinatal morbidity including pre-term babies.

Extrapolating our observations, it can be said that a close vigil, anticipation of complications and appropriate care and interventions during labor and puerperium will help in improving outcomes in these severely anemic women.

\section{Conflict of Interest: Nil}

Funding: Institutional

\section{References}

[1] WHO. The global prevalence of anaemia in 2011. Geneva: World Health Organization; 2015

[2] Suryanarayana R, Chandrappa M, Santhuram AN, Prathima S, Sheela SR. Prospective study on prevalence of anemia of pregnant women and its outcome: A community based study. J of Family Med Prim care. 2017; 6(4): 739-743.

[3] Agarwal KN, Agrawal DK, Sharma A, Sharma K, Prasad $\mathrm{K}$, Kalita MC et al. Prevalence of anemia in pregnant and lactating women in India. Food Nut Bulletin. 2006; 27:311-5

[4] World Health Organisation .The prevalence of anemia in pregnancy, WHO Technical reports(1992-1993).

[5] Prashant D, Jaideep KC, Girija A, Mallapur MD. Prevalence of anemia among pregnant women attending antenatal clinics in rural field practice area of Jawaharlal Nehru Medical College, Belagavi, Karnataka, India. Int J Community Med Public Health. 2017; 4(2): 537-541

[6] Maka SS, Tondare SB, Tondare MB. Study of impactof anemia on pregnancy. Int.J Reprod Contracept Obstet Gynecol. 2017; 6(11): 4847-4850.

[7] Singh S, Kaur K. Maternal outcome in cases of severe anaemia in labour. Int $\mathbf{J}$ Reprod Contracept Obstet Gynecol. 2018; 7(3): 1201-1204.

[8] Sangeetha VB, Pushpalatha.S. Severe Maternal Anemia and Neonatal outcome Sch J App Med Sci 2014; 2 (1c): 303-309.

[9] Marhatta R. Study of anemia in pregnancy and its outcome in Nepal Medical college Teaching Hospital, Kathmandu, Nepal. Nepal Med coll J. 2007; 9: 270-4.

[10] Yadav P. Severe anemia and adverse pregnancy outcome in a tertiary care hospital in North India. Int J Reprod Contracept Obstet Gynecol. 2018; 7(2): 483-486.

[11] Upadhyay $\mathrm{C}$ and Upadhyay N. Effect of anemia on pregnancy outcome: a prospective study at tertiary care hospital. Int J Reprod Contracept Obstet Gynecol. 2017; 6(12): 5379-5383 


\section{International Journal of Innovative Research in Medical Science (IJIRMS) Volume 04 Issue 01 Jan 2019, ISSN: 2455-8737, Imp. Factor - 4.102 Available online at - www.ijirms.in}

[12] Milman N. Prepartum anaemia: prevention and treatment. Ann Hematol. 2008; 87(12): 949-59.

[13] Batar A, Salvi A, Saini L, Agarwal S, Rajoria L and Mital P. Maternal and Perinatal Outcome of Pregnancy with Severe Anaemia. International Journal of Biomedical and Advance Research 2015; 6(08): 611-616.

[14] Gopalakrishnan S, Rama R. Assessment of knowledge regarding 'essential obstetrics care' among rural pregnant women in Kancheepuram District of Tamil Nadu, India. Int J Community Med Public Health. 2015; 2: 526-30.

[15] Abiselvi A, Gopalakrishnan S, Umadevi R, Rama R. Socio-demographic and obstetric risk factors of anaemia among pregnant women in rural Tamil Nadu. Int $\mathbf{J}$ Community Med Public Health. 2018; 5(2): 721-727.

[16] Ghimire RH and Ghimire S. Maternal and fetal outcome following severe anaemia in pregnancy. Journal of Nobel Medical College.2013; 2(1): 22-26

[17] Jaleel R,Khan A. Severe anemia and adverse pregnancy outcome. Journal of Surgery Pakistan (International). 2008; 13 (4): 147-150.

[18] Kumar V, Choudhry VP. Iron Deficiency and Infection. Indian J of Pediatrics. 2010; 77: 789 - 93.

[19] Kaul I, Sunil I, Gupta A. Maternal haemoglobin and perinatal outcome in a tertiary care hospital in Jammu city, India.Int $\mathrm{J}$ Reprod Contracept Obstet Gynecol. 2017; 6(11): 5060-506

[20] Devi BN, Varalaxmi B, Jyothirmayi T, Lahari N. Maternal outcome in pregnancy with severe anaemia: Prospective study in a tertiary care hospital in Andhra Pradesh . IOSR Journal of Dental and Medical Sciences. 2015; 14(4): 6-10.

[21] Frass KA. Postpartum hemorrhage is related to the hemoglobin levels at labor: Observational study. Alexendaria Journal of Medicine. 2015; 51 (4): 333-337

[22] Wandabwa J, Dovle P, Todd J, Ononge S, Kiondo P. Risk factors for severe postpartum hemorrhage in Mulago Hospital, Kampala, Uganda. East Afr Med J 2008; 85: 64-71

[23] Zhang Q, Ananth CV, Zhu Li, Smulian JC; Maternal anaemia and preterm birth: a prospective cohort study. International Journal of Epidemiology. 2009; 38 (5): 1380-1389,
[24] Ali A.A., Rayis DA., Abdallah TM. Elbashir MI, Adam I. Severe anaemia is associated with a higher risk for preeclampsia and poor perinatal outcomes in Kassala hospital, eastern Sudan. BMC Res Notes. 2011; 4: 311.

[25] Singla PN, Tyagi M, Kumar A, Dash D and Shankar R. Fetal Growth in Maternal Anaemia Journal of Tropical Pediatrics. 1997; 43: 89-92

[26] Kozuki N, Lee AC, Katz J. Child Health Epidemiology Reference Group. Moderate to severe, but not mild, maternal anemia is associated with increased risk of small-for-gestational-age outcomes. J Nutr 2012; 142(2): 358-62.

[27] Anjanappa B, Radhika BH, Nataraja HG, Ramaiah R, Sathya P. Maternal haemoglobin and perinatal outcome. Int J Reprod Contracept Obstet Gynecol. 2015; 4(5): 1335-1338

[28] Rizwan N, Uddin SF, Mumtaz F. Maternal anemia impact on maternal and perinatal outcome. Int. $\mathrm{J}$ of Medicine and Med Sci. 2013; 3(1): 328 - 331.

[29] Can C, Topacoglu H, Ucku R. Investigation of Relationship between Blood Hemoglobin Level and Acute Pulmonary Embolism in Emergency Setting. Int Med J. 2013; 20(5): 584-586.

[30] Harringa JB, Bracken RL, Nagle SK, Schiebler ML, Patterson BW, Svenson JE, Repplinger MD. Anemia is not a risk factor for developing pulmonary embolism. Am J Emerg Med. 2017; 35(1):146-149

[31] Kulkarni R, Chauhan S, Daver R, Nandanwar Y, Patil A, Bhosale A. Prospective observational study of near-miss obstetric events at two tertiary hospitals in Mumbai, Maharashtra, India. International Journal of Gynecology and Obstetrics. 2016; 132: 170-173

[32] Chhabra P, Guleria K, Saini NK, Anjur KT, Vaid NB. Pattern of severe maternal morbidity in a tertiary hospital of Delhi, India: a pilot study. Trop Doct. 2008; 38(4):201-4.

[33] Evaluating the quality of care for severe pregnancy complications The WHO near-miss approach for maternal health. WHO 2011. 